\title{
SOSIALISASI DIVERSIFIKASI PRODUK PANGAN FUNGSIONAL BERBASIS SORGUM DI DESA CIMANGGU KECAMATAN PAMEUNGPEUK KABUPATEN BANJARAN
}

\author{
Een Sukarminah, Endah Wulandari, dan Elazmanawati Lembong \\ Departemen Teknologi Industri Pangan Fakultas Teknologi Industri Pertanian, Universitas Padjadjaran \\ Jl Raya Jatinangor KM 21 Jatinangor Sumedang Jawa Barat \\ E-mail: e.sukarminah@yahoo.com
}

\begin{abstract}
ABSTRAK. Biji sorgum memiliki kandungan gizi yang baik, seperti karbohidrat, protein, lemak, mineral, dan vitamin, serta tidak mengandung gluten seperti yang terdapat di dalam gandum, sehingga aman untuk penderita penyakit intoleran terhadap gluten seperti autisme, penyakit seliak, dan lain sebagainya. Tujuan dari program ini adalah sosialisasi diversifikasi produk pangan berbasis sorgum menjadi pangan fungsional, membangun kesadaran untuk memulai berwirausaha dan mengembangkan industri rumah tangga berdasarkan potensi pangan lokal yang dimiliki demi perbaikan kesejahteraan keluarga dan masyarakat sekitar dan melakukan penyuluhan/penyadaran tentang cara pengolahan pangan yang baik dan benar. Hasil dari proses PPM adalah respon warga masyarakat dan aparat kecamatan Pamengpeuk Kabupaten Bandung baik dan positif terhadap kegatan PPM yang akan dilaksanakan selama bulan April sampai dengan Desember 2018 Respon aparat desa sayang dan ibu PKK baik dan mendukung kegiatan dengan batuan perijinan penggunaan fasilitas desa.
\end{abstract}

Kata kunci: Sorgum; Diversifikasi; Desa Cimanggu

\section{SOCIALIZATION OF THE DIVERSIFICATION OF SORGUM BASED FUNCTIONAL FOOD PRODUCTS IN THE VILLAGE CIMANGGU PAMEUNGPEUK SUBDISTRICT BANJARAN REGENCY}

\begin{abstract}
Sorghum grains have good nutritional content, such as carbohydrates, proteins, fats, minerals and vitamins, and do not contain gluten like those found in wheat, making it safe for people with intolerant gluten diseases such as autism, celiac disease, and so on. The aim of this program is to disseminate the diversification of sorghum-based food products into functional food, build awareness to start entrepreneurship and develop home industries based on the potential of local food owned to improve the welfare of families and surrounding communities and conduct counseling / awareness on good food processing and right. The result of the servive community process is the response of the residents and Pamengpeuk sub-district officials of Bandung Regency both to the service community activities that will be held from April to December 2018 Response from the village officials and civil village is good and supports activities with rocks permitting the use of village facilities.
\end{abstract}

Keywords: Sorghum; Diversification; Cimanggu Village

\section{PENDAHULUAN}

Sorgum mengandung senyawa oligosakarida yang terdiri dari rafinosa, stakiosa dan verbaskosa. Senyawa oligosakarida yang terkandung dalam tepung sorgum tersebut merupakan bahan prebiotik. Senyawa tersebut tidak dapat dicerna di dalam tubuh, namun dapat memberikan manfaat positif bagi tubuh karena secara selektif menstimulir pertumbuhan dan aktivitas bakteri baik dalam usus besar, sehingga dapat meningkatkan ketahanan sistem pencernaan (Gibson dan Roberfroid,1995 dikutip Sirappa, 2003).

Sorgum adalah tanaman serealia utama setelah gandum, beras dan jagung. Sorgum dibudidayakan di banyak negara dan sekitar $80 \%$ areal pertanaman berada di Afrika dan Asia. Tanaman sorgum merupakan tanaman multiguna yang memiliki kandungan nutrisi tinggi sehingga dapat menjadi salah satu alternative pemecahan masalah pangan yang terjadi di Indonesia.

Bagian biji, batang dan daun tanaman sorgum dapat dimanfaatkan untuk kebutuhan manusia, ternak unggas dan ternak ruminansia (Hubbard,dkk., 1968). Keunggulan lainnya dari tanaman sorgum adalah memiliki daya adaptasi yang tinggi, yaitu dapat tumbuh di hampir semua jenis lahan, tahan kekeringan, dapat berproduksi pada lahan marginal, serta relatif tahan terhadap gangguan hama dan penyakit.

Di Indonesia, pengembangan dan budidaya sorgum masih terbatas di beberapa wilayah, seperti Nusa Tenggara Timur, Jawa Barat, dan Jawa Tengah, baik sebagai bahan pangan lokal maupun pakan ternak (Susilowati dan Saliem, 2013). Hal ini akan terus meningkat dengan perkembangan tanaman sorgum sebagai pangan, pakan, dan energi alternatif. Peningkatan produksi sorgum di dalam negeri perlu mendapat perhatian khusus karena Indonesia sangat potensial bagi pengembangan sorgum. Subagio dan Saraswati (2013) dikutip Subagio dan Aqil (2014) menyatakan bahwa wilayah produksi sorgum yang pada awalnya berpusat di Pulau Jawa, telah berkembang hingga ke Sulawesi dan Nusa Tenggara. Khusus di wilayah Jawa Barat, sorgum 
dibudidayakan di Kabupaten Banjaran. Sorgum yang dibudidayakan adalah sorgum putih kultivar lokal bandung.

Biji sorgum putih kultivar lokal bandung dapat diolah menjadi tepung sorgum. Kelebihan dari tepung sorgum adalah memiliki kandungan pati yang cukup tinggi, yaitu sekitar 80,42\% (Suarni, 2004). Biji sorgum memiliki kandungan gizi yang baik, seperti karbohidrat, protein, lemak, mineral, dan vitamin, serta tidak mengandung gluten seperti yang terdapat di dalam gandum, sehingga aman untuk penderita penyakit intoleran terhadap gluten seperti autisme, penyakit seliak, dan lain sebagainya (Mardawati dkk, 2010).

Tujuan dari program ini adalah diversifikasi produk pangan berbasis sorgum menjadi pangan fungsional, membangun kesadaran untuk memulai berwirausaha dan mengembangkan industri rumah tangga berdasarkan potensi pangan lokal yang dimiliki demi perbaikan kesejahteraan keluarga

\section{METODE}

Agar program ini dapat dilaksanakan sesuai tujuan dan target yang akan dicapai, maka metode pelaksanaan program yang akan diterapkan adalah sebagai berikut :

1. Sosialisasi kepada pejabat desa, kecamatan dan kabupaten terkait program; hal ini dimaksudkan untuk menggalang kekuatan agar dalam pelaksaan program ini tidak hanya didukung oleh satu pihak saja, yaitu kampus sebagai pelaksana program PKM, namun juga ada partisipasi aktif warga setempat dalam pelaksanaannya

2. Kesadaran berwirausaha

2.1. Membangkitkan kesadaran untuk berwirausaha bagi yang belum memiliki usaha dan kesadaran untuk mengembangkan usaha bagi yang yang telah memiliki usaha sebelumnya.

2.2. Merumuskan masalahan utama yang harus diselesaikan

2.3. Merumuskan solusi yang akan dilaksanakan secara bersama.

3. Kesadaran akan cara produksi pangan yang baik (CPPB-IRT)

4. Pelatihan Pembuatan Produk Pangan Fungsional berbasis sorgum

4.1. Pengenalan beberapa metode yang dilakukan dalam inovasi produk

4.2. Pengenalan inovasi produk yang dapat dilakukan untuk industri makanan olahan.

4.3. Mengenalkan beberapa contoh inovasi produk yang bisa dilakukan dalam meningkatkan harga jual dan sasaran konsumen, seperti peningkatan kualitas produk, kualitas kemasan, sistem pemasaran, dll.

\section{HASIL DAN PEMBAHASAN}

\section{Sosialisasi Pembuatan Produk Pangan Fungsional Berbasis Sorgum}

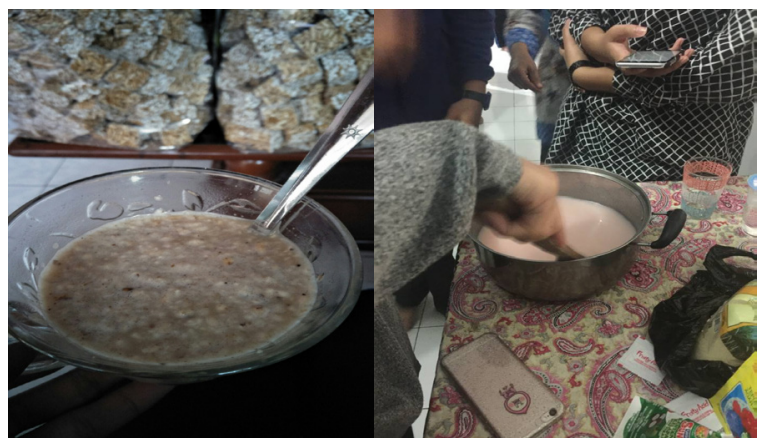

Ditinjau dari nilai gizinya sorgum mengandung karbohidrat yang cukup tinggi yaitu sebesar $83 \%$, protein $11 \%$, lemak 3,3\% vitamin B1, mineral Fe, $\mathrm{P}$ dan $\mathrm{Ca}$ dalam jumlah yang cukup untuk memenuhi kebutuhan tubuh (Hulse, Laing, dan Pearson, 1980). Dari survai yang telah dilakukan oleh Mudjisihono dan Suprapto (1987) di daerah Jawa Tengah dan Jawa Timur ternyata biji sorgum dimanfaatkan dalam pembuatan makanan ringan seperti wajik, lemper dan dodol serta sebagai pengganti beras khususnya pada musim paceklik. Sorgum di beberapa negara di Asia juga telah dimanfaatkan sebagai bahan baku produk pangan seperti roti, cake, mi, kue kering dan. minuman fermentasi.

\section{Sosialisasi Potensi Kewirausahaan Produk Pangan Berbasis Sorgum}
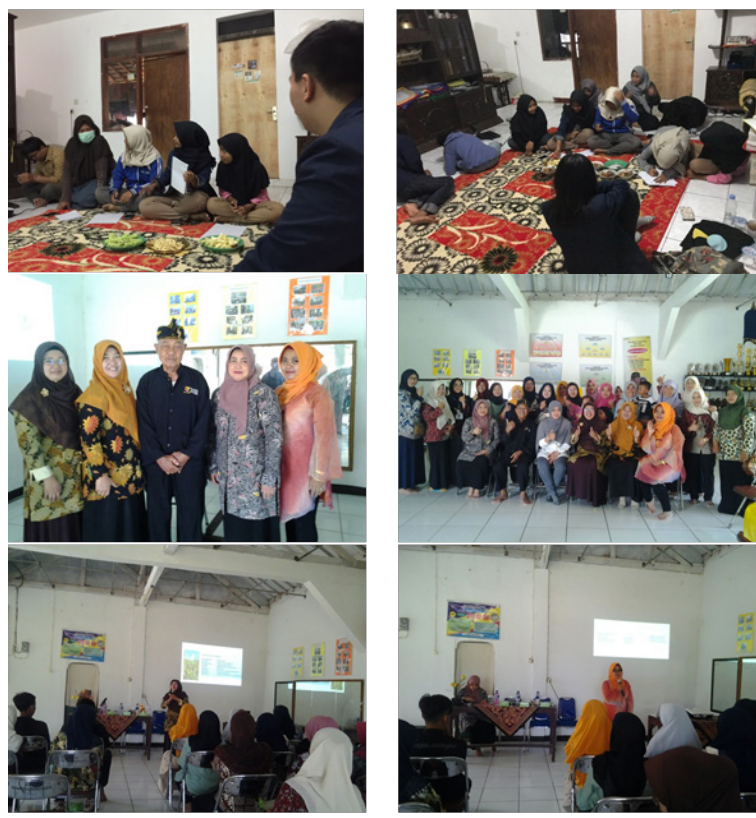

Respon yang diberikan warga desa dan aparat desa cimanggu terhadap acara sosialisasi sangat baik yang dapat dilihat dari foto-foto dokumentasi kegiatan. Warga dan aparat desa antusias mengikuti 
acara sosialisasi kewirausahaan dan expo kecil produk-produk pangan berbasis sorgum.

\section{SIMPULAN}

Respon aparat kecamatan Pamengpeuk Kabupaten Bandung baik dan positif terhadap kegatan PKM yang dilaksanakan selama bulan April sampai dengan Agustus 2018 dan KKN Mahasiswa yang dilaksanakan hingga bulan Desember 2018; Respon aparat desa sayang dan ibu PKK baik dan mendukung kegiatan dengan batuan perijinan penggunaan fasilitas desa

\section{DAFTAR PUSTAKA}

Badan Standardisasi Nasional. 1993. Standar Nasional Indonesia. Syarat Mutu Kue Kering (cookies). SNI 01-2973-1993. Badan Standardisasi Nasional. Jakarta.

Kebakile, M.M. 2008. Sorghum Dry Milling Processes and Their Influence on Meal and Porridge Quality. Thesis. Department of Food Science, Faculty of Natural and Agriculture Science, University of Pretoria, Pretoria, Republic of South Africa.
Mardawati, Efri., Een Sukaminah, Tino mutiarawati Onggo, Carmencita T, Rossi Indiarto. 2010. Pengolahan Sorgum. Penerbit Pustaka Giratuna. Bandung

Mudjisihono \& Suprapto, 1987. Budidaya dan Pengolahan Sorgum. Jakarta: Penebar Swadaya.

Rukmana, R dan Y.Oesman. 2001. Usaha Tani Sorgum. Kanisius. Jakarta.

Soekarto, S.T. 1985. Penilaian Organoleptik untuk Industri Pangan dan Hasil Pertanian. Bhratara Karya Aksara. Jakarta.

Suarni. 2004. Pemanfaatan Tepung Sorgum Untuk Produk Olahan. Jurnal Litbang Pertanian. Vol 23 (4): 145-151.

Sirappa, M. P. 2003. Prospek Pengembangan Sorgum di Indonesia Sebagai Komoditas Alternatif untuk Pangan, Pakan, dan Industri. Balai Pengkajian Teknologi Pertanian, Sulawesi Selatan

Subagio, H., dan Aqil, M. 2014. Perakitan dan Pengembangan Varietas Unggul Sorgum untuk Pangan, Pakan, dan Bioenergi. Balai Penelitian Tanaman Serealia, Sulawesi Selatan 